\title{
PARTHENOGENESIS IN THE TROPICAL GEKKONID LIZARD, NACTUS ARNOUXII (SAURIA: GEKKONIDAE)
}

\author{
Craig Moritz \\ Laboratory of Molecular Systematics, Museum of Zoology and Department of Biology, \\ University of Michigan, Ann Arbor, MI 48109
}

\begin{abstract}
As currently diagnosed, Nactus arnouxii includes unisexual and bisexual populations. The geographic distribution of each type was estimated by sex-ratio analysis of samples from southwestern Pacific islands. Males were absent from southern Vanuatu (excluding Aneityum), New Caledonia, and all islands to the east that have been sampled. Both types of populations appear to be present on Aneityum. Chromosome and protein analyses showed that the bisexual populations are highly polytypic and probably consist of more than one biological species. The unisexual $N$. arnouxii were diploid, highly heterozygous, and showed no genetic segregation. The absence of segregation suggests clonal reproduction, substantiating parthenogenesis. The high heterozygosity of the unisexuals indicates their origin through hybridization. One parent was genetically similar to the extant bisexual population from northern Vanuatu. The other parent has not been identified, but its genetic characteristics are predicted by phylogenetic analysis.
\end{abstract}

Received January 27, 1987. Accepted June 5, 1987

Clonal mechanisms of reproduction occur in a small proportion of vertebrate species: sperm-dependent modes (hybridogenesis and gynogenesis) have been documented for a few species of fish and amphibians (reviewed by Schultz [1969], White [1978], and Bell [1982]), while true parthenogenesis occurs sporadically in seven of the 17 families of lizards and in one species of blind snake (reviewed by Cole [1975], and Darevsky et al. [1985]). Among geckos (family Gekkonidae), five parthenogenetic species are known, and at least two of these also include sexually reproducing populations (reviewed by Moritz and King [1985]). Comparative studies of parthenogenetic and bisexual relatives can provide important insights into the evolutionary significance of sex and genetic diversity (reviewed by Bell [1982]). However, the origins of parthenogenetic lineages must be resolved before such comparisons can be properly interpreted.

Nactus arnouxii (formerly Cyrtodactylus pelagicus) is a small terrestrial gecko, distributed from Papua New Guinea and northeastern Australia to the islands of the central Pacific Ocean (Kluge, 1983). This is one of the few lizard species to have colonized the region east of Fiji (Fig. 1), and it occupies a wide range of habitats from disturbed littoral situations to climax rainforest (Cogger and Heatwole, 1981; Gibbons, 1985). Little is known of the population biology of this species, but Schwaner (1980) found only females in a series of 51 specimens of $N$. arnouxii from American Samoa. Preliminary data (discussed below) suggest that these represent a unisexual species that reproduces parthenogenetically.

In this paper, the geographic distribution of bisexual and parthenogenetic populations is estimated from the sex ratio of museum samples of $N$. arnouxii. This analysis is complemented by assays of chromosomal and electrophoretic variation in freshly collected specimens from bisexual and parthenogenetic populations.

\section{Materials AND METHOdS}

Morphology. - The sexes of 1,580 specimens of $N$. arnouxii were determined from external characteristics. Conspicuous preanal pores are present in adult males but not females. The gonads of freshly killed specimens were also examined to verify sex. Specimens smaller than $30 \mathrm{~mm}$ snout-vent did not have conspicuous preanal pores and were therefore excluded from the analysis. With the exception of specimens from New Britain, mainland Papua New Guinea, and Australia, all geckos from a given island were pooled to maximize sample size for statistical tests. Deviations from a $1: 1$ sex ratio were tested using the $\chi^{2}$ test with Yates' correction.

Cytogenetics. - Metaphase-chromosome spreads were obtained from short-term leucocyte cultures (modified from de Boer et 
TABLE 1. Conditions for electrophoresis. All gels were run at $10-12 \mathrm{~V} / \mathrm{cm}$ at $4^{\circ} \mathrm{C}$. Tissues: $\mathrm{L}=$ liver, $\mathrm{M}=$ skeletal muscle. Numeric code for buffers (in column for "Conditions"): 1) $50 \mathrm{mM}$ Tris, $5 \mathrm{mM}$ EDTA, $1 \mathrm{mM}$ $\mathrm{MgCl}_{2}$, pH 7.8 with maleic acid; 2) $15 \mathrm{mM}$ Tris, $5 \mathrm{mM}$ EDTA, $1 \mathrm{mM} \mathrm{MgCl} 2$, pH 7.8 with maleic acid; 3) 15 $\mathrm{mM}$ Tris, $5 \mathrm{mM}$ EDTA, $1 \mathrm{mM} \mathrm{MgCl}$, $\mathrm{pH} 8.2$ with boric acid; 4) $100 \mathrm{mM}$ Tris, $\mathrm{pH} 8.2$ with citric acid; 5) 20 $\mathrm{mM}$ phosphate, $\mathrm{pH}$ 7.0. Where necessary, approximately $10 \mathrm{mg}$ of the cofactors were added to the gel-soaking and running buffers. "Nothing" dehydrogenase was stained in the presence of NADP and $\mathrm{MgCl}_{2}$ but no exogenous substrate. Its activity was not affected by inhibitors of LDH or ADH. Enzyme Commission numbers are taken from Richardson et al. (1986).

\begin{tabular}{|c|c|c|c|}
\hline Protein system (abbreviation, E.C. number) & Tissue & $\begin{array}{l}\text { Number } \\
\text { of loci } \\
\text { scored }\end{array}$ & Conditions \\
\hline Aconitase (ACON, 4.2.3.1) & $\mathrm{L}$ & 2 & $1,1.5 \mathrm{hr}$ \\
\hline Adenylate kinase ( $\mathrm{AK}, 2.7 .4 .3$ ) & M & 1 & $1,2 \mathrm{hr}$ \\
\hline Alanine amino transferase (GPT, 2.6.1.2) & $\mathrm{L}$ & 1 & $4,1 \mathrm{hr}$ \\
\hline Alcohol dehydrogenase (ADH, 1.1.1.1) & $\mathrm{L}$ & 2 & $3, \mathrm{NAD}, 3 \mathrm{hr}$ \\
\hline Aspartate amino transferase (GOT, 2.6.1.1) & $\mathbf{L}$ & 2 & $4,2 \mathrm{hr}$ \\
\hline Fumarase (FUM, 4.2.1.2) & $\overline{\mathbf{L}}$ & 1 & $4, \mathrm{NAD}, 3 \mathrm{hr}$ \\
\hline Fructose biphosphate aldolase (ALD, 4.1.2.13) & M & 1 & 1, NAD, $3 \mathrm{hr}$ \\
\hline General protein (GP) & M & 2 & $1,3 \mathrm{hr}$ \\
\hline Glucose phosphate isomerase (GPI, 5.3.1.9) & $\mathbf{M}$ & 1 & $3,2.5 \mathrm{hr}$ \\
\hline Glyceraldehyde-phosphate dehydrogenase ( $\alpha \mathrm{GPD}, 1.2 .1 .12$ ) & $\mathrm{L}$ & $i$ & $3, \mathrm{NAD}, 2 \mathrm{hr}$ \\
\hline Glycerol-3-phosphate dehydrogenase (GA3PD, 1.1.1.8) & $\mathrm{L}$ & 1 & $3, \mathrm{NAD}, 2 \mathrm{hr}$ \\
\hline Hexokinase (HK, 2.7.1.1) & $\bar{M}$ & 1 & $1, \mathrm{NADP}, 2 \mathrm{hr}$ \\
\hline Isocitrate dehydrogenase (IDH, 1.1.1.42) & $\mathrm{L}$ & i & $4,2 \mathrm{hr}$ \\
\hline Lactate dehydrogenase (LDH, 1.1.1.27) & $\mathrm{L}$ & 2 & $3,3 \mathrm{hr}$ \\
\hline "Nothing" dehydrogenase (NDH) & $\mathrm{L}$ & 1 & $1, \mathrm{NADP}, 2 \mathrm{hr}$ \\
\hline Mannose phosphate isomerase (MPI, 5.3.1.8) & $\mathrm{L}$ & 1 & $1, \mathrm{NADP}, 0.5 \mathrm{hr}$ \\
\hline Peptidase D: L-leucyl-proline (PEPLP, 3.4.13.9) & $\mathbf{L}$ & 1 & $3,1.5 \mathrm{hr}$ \\
\hline Peptidase: L-lelicyl-glycyl-glycine (PEPLGG, 3.4.11) & $\overline{\mathbf{L}}$ & 1 & $1,1.5 \mathrm{hr}$ \\
\hline Phosphogluconate dehydrogenase (6PGD, 1.1.1.44) & $\mathbf{L}$ & 1 & $1 / 3, \mathrm{NADP}, 1.5 \mathrm{hr}$ \\
\hline Phosphoglucomutase (PGM, 2.7.5.1) & $\mathbf{L}$ & 2 & $2,2 \mathrm{hr}$ \\
\hline Phosphoglycerokinase (PGK, 2.7.2.3) & $\mathrm{M}$ & 1 & $4,1.5 \mathrm{hr}$ \\
\hline Phosphopyruvate hydratase (ENO, 4.2.1.11) & $\mathrm{L}, \mathrm{M}$ & 2 & $5,3 \mathrm{hr}$ \\
\hline Pyruvate kinase (PK, 2.7.1.40) & $\mathrm{M}$ & 1 & $1,2 \mathrm{hr}$ \\
\hline Sorbitol dehydrogenase (SORDH, 1.1.1.14) & $\mathbf{L}$ & 1 & $1, \mathrm{NAD}, 1 \mathrm{hr}$ \\
\hline Superoxide dismutase (SOD, 1.15 .1 .1$)$ & $\mathrm{L}$ & 1 & (any) \\
\hline Triose phosphate isomerase (TPI, 5.3.1.1) & $\mathbf{M}$ & 1 & 1, NAD, $3 \mathrm{hr}$ \\
\hline
\end{tabular}

al. [1977] by growing cultures at $30^{\circ} \mathrm{C}$ and excluding antibiotics), direct in vitro preparations of spinal bone marrow (Christidis, 1984), and, for one specimen from New Caledonia, squash preparations of intestinal epithelium (provided by A. Bauer; method in Kezer and Sessions [1979]). Air-dried meiotic preparations were made according to King and Rofe (1976), but without colchicine treatment. The C-banding protocol is given in Moritz (1984). Chromosome counts are based on five to ten cells per individual. Chromosome arms are identified on the basis of their length. In the absence of G-banding analyses, their assignment to particular fusions is tentative.

Electrophoresis. - Gel electrophoresis of liver and skeletal muscle extracts was conducted on cellulose acetate ("Cellogel," Chemetron, Milan; methods in Richardson et al. [1986]). The tissue was ground in an equal volume of a Tris-EDTA buffer (Selander et al., 1971) and centrifuged at 13,600 $g$ for 10 minutes; the supernatant was then stored at $-170^{\circ} \mathrm{C}$. The remaining samples are stored by the Evolutionary Biology Unit of the South Australian Museum. Voucher specimens collected by the author are held by the Australian Museum and the University of Michigan Museum of Zoology. The electrophoretic conditions used in this study are given in Table 1.

\section{RESULTS}

Distribution of All-Female Populations. The sex ratios of the $N$. arnouxii samples are summarized in Table 2 and Figure 1. Males were found in all samples from northern Vanuatu (formerly New Hebrides) to northeastern Australia and Papua New 


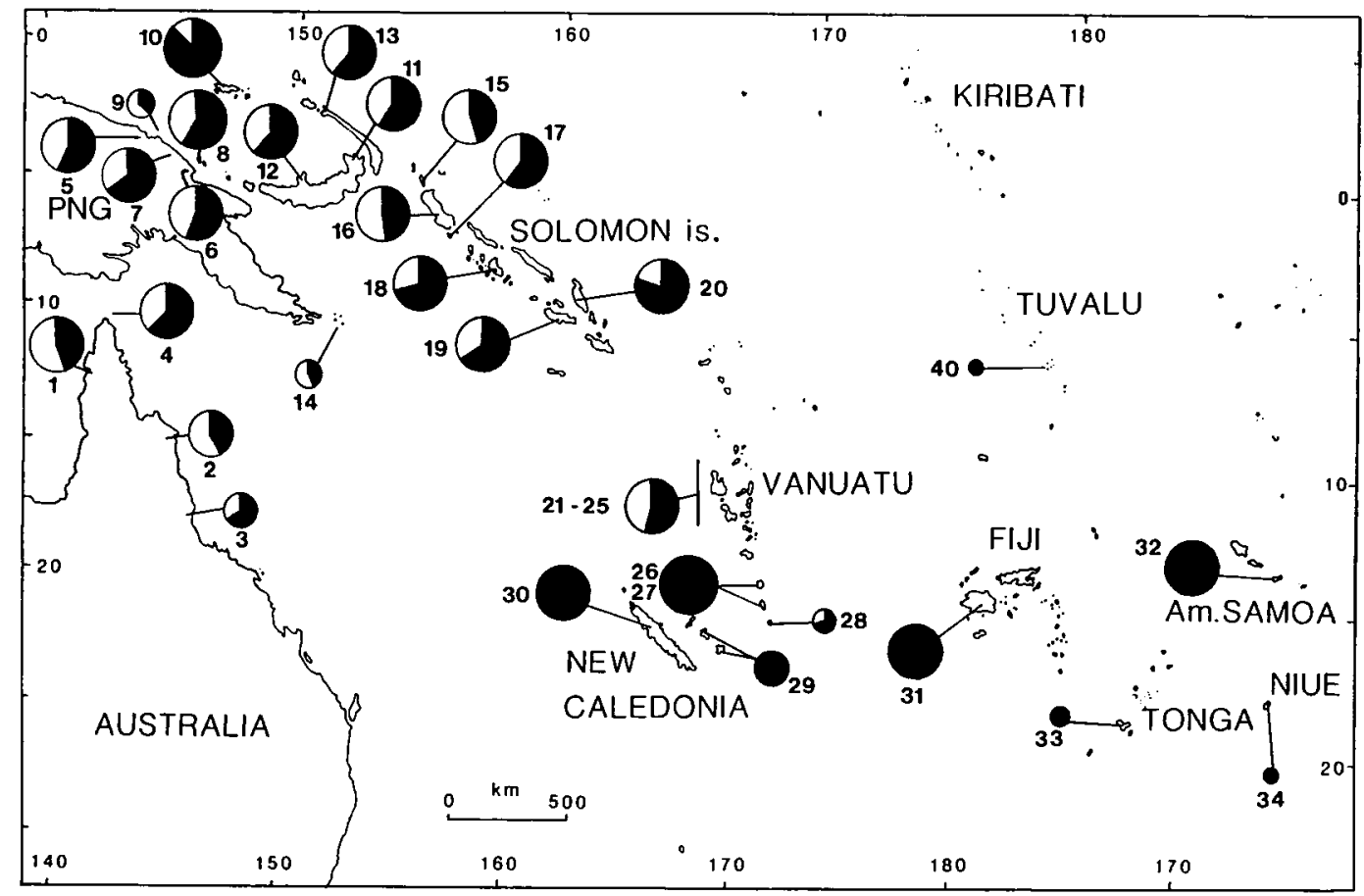

FIG. 1. Geographic variation in the sex ratios of museum series of $N$. arnouxii. The solid part of each circle is the frequency of females. For samples of fewer than 20 specimens, the areas of the circles decrease with sample size. Numbers refer to localities listed in Table 2. Note the absence of males from south Vanuatu (excluding Aneityum), New Caledonia, and the islands to the east. The small, all-female samples from Micronesia and Tahiti (Table 2) are not shown.

Guinea. Males were absent from Micronesia, the southern islands of the Vanuatu archipelago (excluding Aneityum; see below), the Loyalty islands, New Caledonia, and all surveyed areas to the east. A boundary between the bisexual and all-female populations is evident between adjacent islands of the Vanuatu chain (Fig. 2).

The boundary between the two types of populations in Vanuatu coincides with a change in external morphology. $N$. arnouxii from the all-female populations invariably have small postmental scales with one or more granules separating the postmental from the junction of the mental and the first infralabial scales (Fig. 3B). In contrast, all $N$. arnouxii from Efate to the Banks Islands (numbers $21-25$ in Fig. 2) had the large postmental scale (Fig. 3A). Of the Aneityum specimens, two were females with the reduced postmental scale, while the other five, including three males, had the large scale characteristic of bisexual populations from Vanuatu. These data suggest that both types of populations are present on Aneityum. However, the reduced postmental scale cannot be used to diagnose parthenogens in areas other than Vanuatu, since both males and females from the Solomon islands and Papua New Guinea occasionally showed this condition.

Chromosome Variation. - The cytogenetic analysis of bisexual and parthenogenetic $N$. arnouxii revealed considerable variation (Table 3). The number of chromosome pairs varies from 20 to 14 , while the number of major-chromosome arms (excluding the small arms of the acrocentric pair 2) is 42 in all but the Papua New Guinea samples. In high- and low-chromosomenumber forms, C-band heterochromatin is largely restricted to the centromeres and telomeres (Fig. 4). The major mechanism of chromosome change in this species therefore appears to be whole-arm translocations, rather than addition/deletion of whole-arm heterochromatin.

The four specimens of $N$. arnouxii from 
Port Moresby, Papua New Guinea had 40 major chromosome arms instead of the 42 seen in other $N$. arnouxii (Figs. 5A, 6A; Table 3 ). Furthermore, all four were heterozygous for one centric fusion (Figs. 5A, 6A). This sample included representatives of two morphs (large and small) that may be distinct species (D. Black, pers. comm.). All three specimens of the small morph were heterozygous for the same centric fusion $(2 n=39 \mathrm{~A}$; arms $1+6$; Fig. 6A). As expected, a trivalent with end-to-end pairing was observed in the meiosis of a male (Fig. 6B). The single specimen of the large morph was also heterozygous for a centric fusion, but in this case at least one of the chromosomes involved was different $(2 n=39 \mathrm{~B}$; arms $6+8$; Fig. 5A).

All of the specimens from Australia (Table 3) had $2 n=38$ chromosomes including two pairs of large biarmed chromosomes (Fig. 5B). On the basis of their relative arm lengths, these probably represent fusions between arms 1 and 5 and between arms 2 and 3 , respectively.

The bisexual $N$. arnouxii from Vanuatu had a very different karyotype. These individuals had only 14 pairs of chromosomes, of which seven were metacentric or submetacentric (Fig. 5C). The number of major chromosome arms was the same as in the $2 n=38$ form from Australia. The largest pair of chromosomes (arms $1+3$ ) appears to differ from the large metacentrics in the $2 n=38$ karyotype (cf. Figs. 5B, C). The largest acrocentric pair (pair 2 in Fig. 5C) differs from the uniarmed pair 2 of the high-chromosome-number karyotypes by a pericentric rearrangement. The other biarmed chromosomes appear to be the result of successive centric fusions (see below).

Representatives of the all-female populations from the geographically distant islands of Niue, Viti Levu (Fiji), Tana (Vanuatu), and New Caledonia were karyotyped (Table 3, Fig. 1). All had $2 n=35$ chromosomes, of which seven were meta- or submetacentric (Fig. 5D). None of the biarmed chromosomes could be consistently paired with one another $(N=65$ metaphases). Parthenogenetic $N$. arnouxii therefore appear to be heterozygous for seven centric fusions and one pericentric rearrangement (Fig. 5D). All of the biarmed

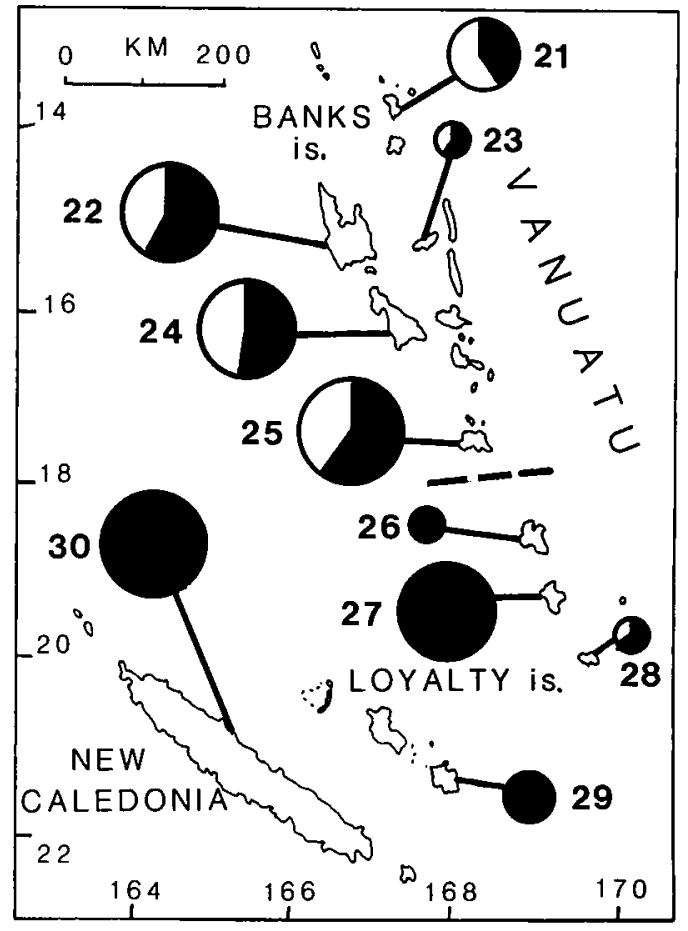

FIG. 2. Details of the distribution and sex ratios of $N$. arnouxii samples from the Vanuatu-New Caledonia region. Symbols and numbers as for Figure 1. Males are absent from the region to the south of Efate except for the sample from Aneityum, which appears to have both types of populations (see text). The boundary between the all-female and bisexual populations is indicated by the broken line.

chromosomes of the parthenogens have morphologically identical counterparts in the bisexual $2 n=28$ population from northern Vanuatu (cf. Figs. 5C, D).

Allozyme Variation. - Electrophoretic variation in proteins was assayed for parthenogens from Fiji and Niue and from representatives of each of the karyotypic forms of the bisexuals (Table 3). Patterns of allelic variation were compared for 33 presumed gene loci from 25 protein systems in all samples except for the single $2 n=39 \mathrm{~B}$ individual for which 29 loci were assayed (Table 3 ). Of the 33 loci, eight were invariant ( $G p t$, Got-2, Ldh-B, Pgm-1, Gp-1, Ak, Eno-1, and Eno-2). The gene frequencies for the remaining 25 loci are given in Table 4 .

The level of observed heterozygosity within the bisexual populations is low, ranging from 0.01 in the $2 n=28$ sample to 0.04 in the $2 n=38$ individuals (Table 3). In 
TABLE 2. The numbers of males $(M)$ and females $(F)$ in samples of $N$. arnouxii. Map numbers refer to Figures 1 and 2. Males are absent from material from southern Vanuatu (excepting Aneityum), New Caledonia, and the islands to the east. Some other samples, particularly those from the Solomon islands, have significantly more females than males. Samples 4, 17, and 29 represent specimens from several immediately adjacent islands that were pooled to provide numerically adequate series. Deviations from a 1:1 sex ratio were tested for in samples 1-25 using the $\chi^{2}$ test with Yates' correction. For probabilities $(P)$, a: $0.05<P<0.10$; b: $0.005<P<0.05$; c: $P<0.005$; ns: $P>0.10$; nt: not tested.

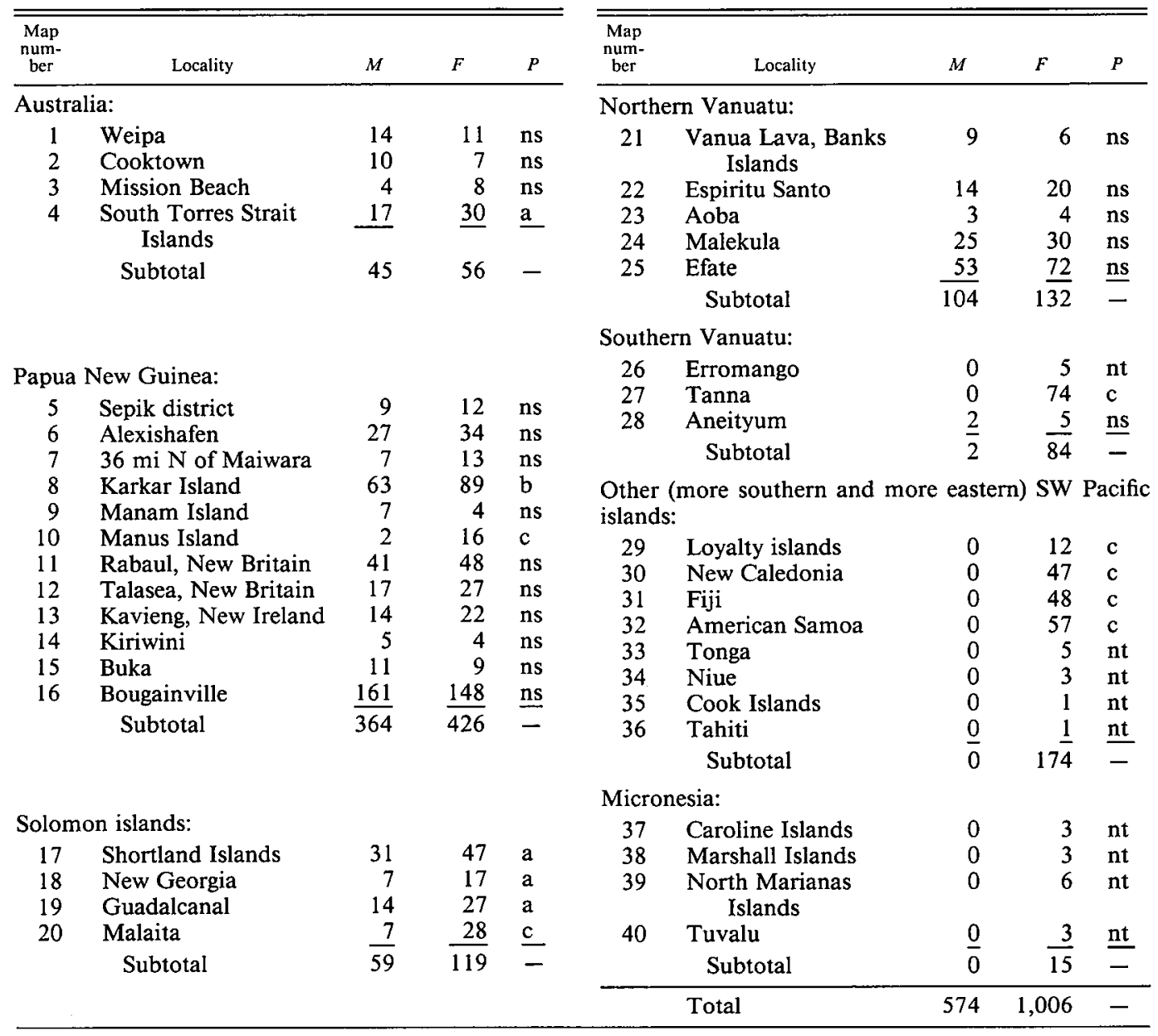

contrast, the parthenogens were fixed heterozygotes at nine of the $33 \mathrm{loci}$, which corresponds to a heterozygosity of 0.27 .

The genetic distances between the bisexual samples are generally high, ranging up to a value of 1.0 (Table 5). The exception is the comparison between the large and small morphs from Port Moresby, which were separated by a genetic distance of only 0.1 (Table 5).

Only a single genetic clone was evident among the six parthenogens assayed electrophoretically, and this was very distinct from all of the bisexual $N$. arnouxii, except for the $2 n=28$ Vanuatu sample (Table 5), which shared alleles with the parthenogens at 30 of the 33 loci.

\section{DISCUSSION}

Genetic Diversity among Bisexual N. arnouxii.-Although few populations have been studied, the high levels of chromosome and protein variation among the bisexual $N$. arnouxii suggest that they represent more than one biological species. Karyotypic evolution by whole-arm translocations is common among gekkonid liz- 


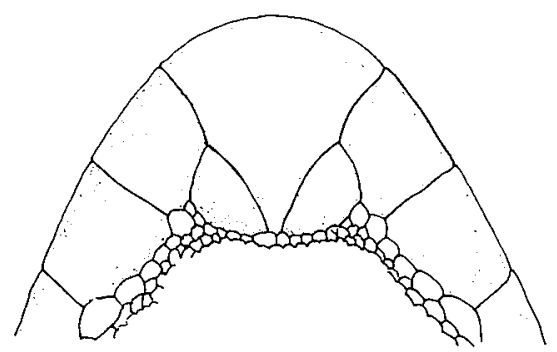

$1 \mathrm{~mm}$

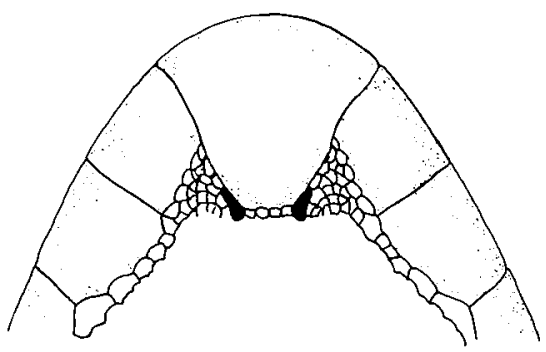

FIG. 3. Variation in the size of the postmental scale of $N$. arnouxii. A) The scale is large (after Kluge [1983 fig. 3]). B) The scale (solid) is reduced and separated from the junction of the mental and first infralabial scales by small granules. The latter condition is found in all 273 specimens of the parthenogenetic form examined to date.

ards (King, 1981; Moritz, 1986). In the event of secondary contact between the low-chromosome-number form from Vanuatu and either of the high-chromosome-number lineages, the karyotypic differences alone may suffice to cause reproductive isolation. Regular segregation of chromosomes in the meiosis of hybrids could be disturbed in two ways: each heterozygous translocation could form a trivalent (e.g., Fig. 6B) which is prone to a low level of malsegregation (see White, 1978; Walsh, 1982) or the presence of the same chromosome arm in different centric fusions (monobrachial homology) could lead to the formation of higher-order multivalents and, thus, a substantial reduction in fertility (Capanna, 1982; Baker and Bickham, 1986; Moritz, 1986).

The electrophoretic data are compatible with the presence of more than one gene pool among bisexual $N$. arnouxii. The genetic distances between recognized species of lizards are highly variable (Avise and Aquadro, 1982), but the values between the samples of $N$. arnouxii from Australia, Papua New Guinea, and Vanuatu would be considered large for interspecific comparisons. As a corollary, the substantial genetic

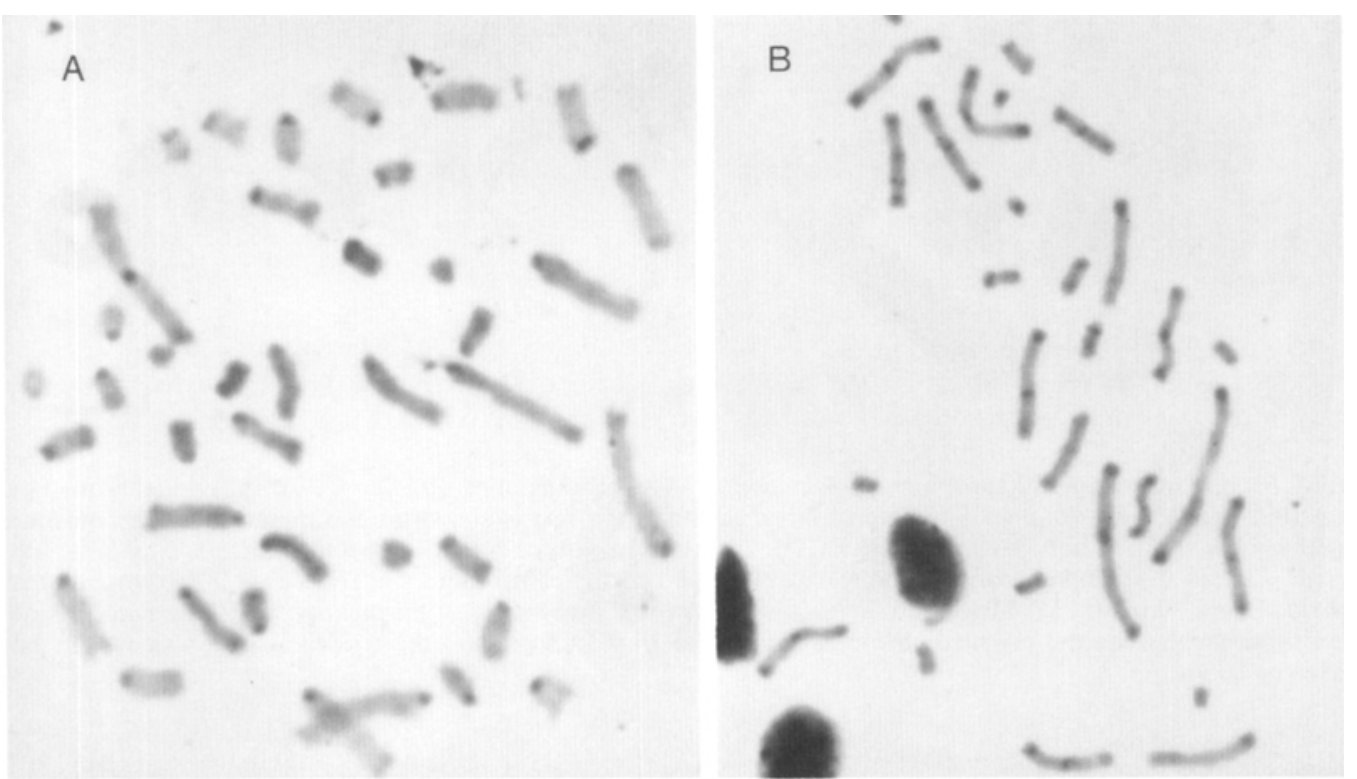

FIG. 4. C-banded mitotic metaphase cells of A) the $2 n=39 \mathrm{~B}$ and B) the $2 n=28$ karyotypes of $N$. arnouxii. $\mathrm{C}$-band heterochromatin is almost exclusively telomeric and centromeric. 
A

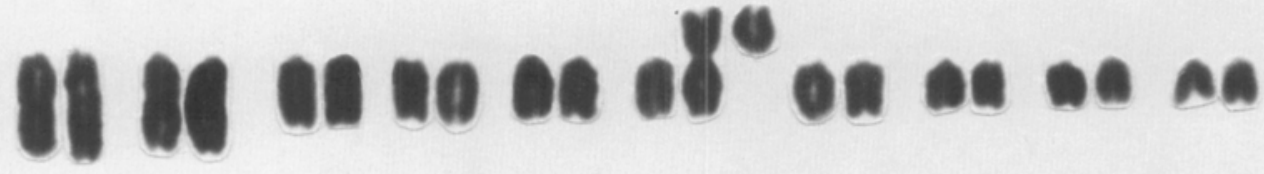

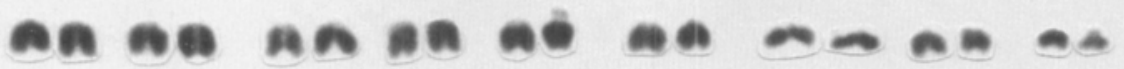

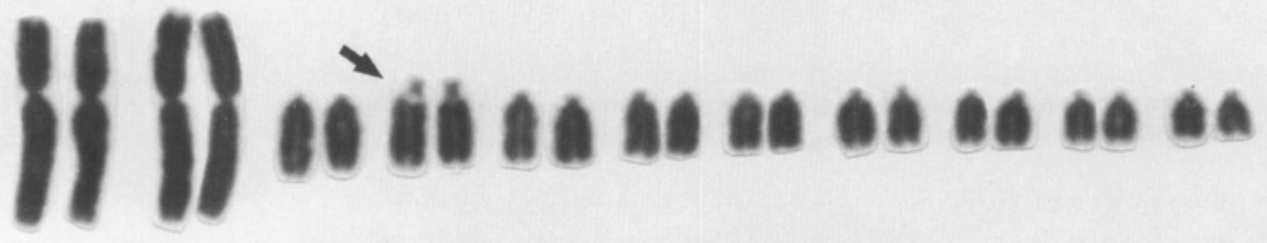

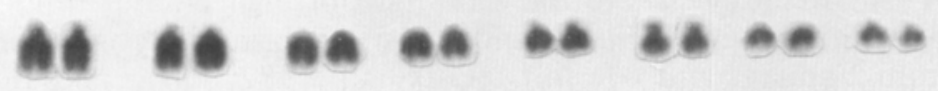

C

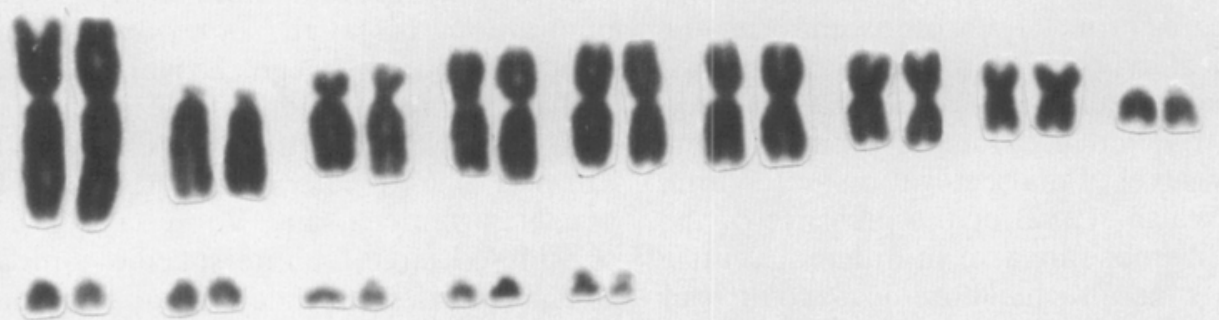

D

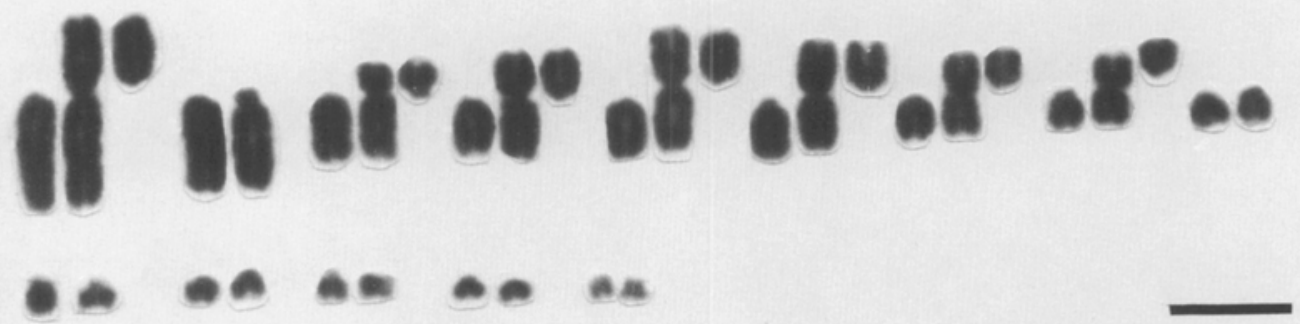

FIG. 5. Giemsa-stained karyotypes of $N$. arnouxii. A) Chromosomes of a $2 n=39 \mathrm{~B}$ individual from Port Moresby, Papua New Guinea. The heterozygous fusion (sixth set) is shown as the metacentric chromosome together with the two homologous arms. B) The $2 n=38$ karyotype found in specimens from Australia. The fourth pair has a secondary constriction (arrow) adjacent to the centromere. C) The $2 n=28$ karyotype of $N$. arnouxii from Vanuatu. D) The highly heterozygous $2 n=35$ karyotype of parthenogenetic $N$. arnouxii. Note the similarity between the biarmed chromosomes of the $2 n=28$ form and those of the parthenogens. The bar indicates $10 \mu \mathrm{m}$. 

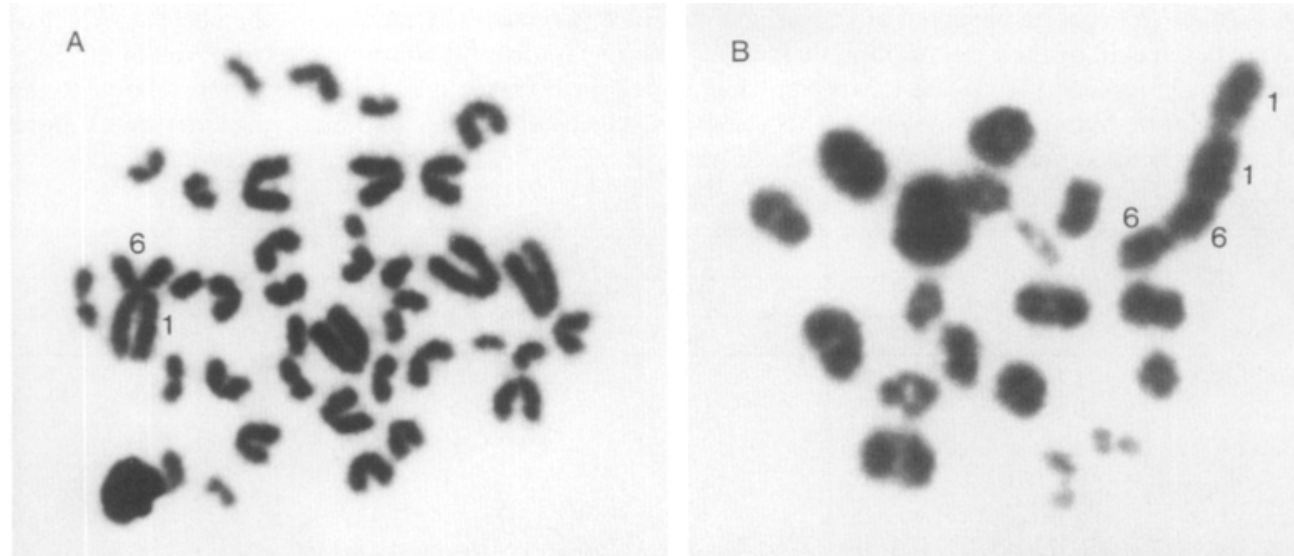

FIG. 6. A) Mitotic and B) meiotic metaphase spreads from a $2 n=39 \mathrm{~A}$ specimen of the "small morph" from Port Moresby. Heterozygosity for a centric fusion is indicated by the unpaired metacentric chromosome in A. In meiosis, the metacentric chromosome and its two homologues regularly form a trivalent.

divergence between the populations indicates that they have been isolated for a long time. Even allowing for substantial rate variation (Avise and Aquadro, 1982), the genetic distances between these lineages suggest that they have been evolving independently since the Tertiary (i.e., $>2 \mathrm{MY}$ ).

The Distribution of Parthenogenesis in N. arnouxii.-The main evidence for parthenogenetic reproduction in $N$. arnouxii is the absence of males from several large series of specimens. Continued reproduction by females in the absence of males is shown by the presence of both juveniles and egg-bear- ing females in these populations. Other possible explanations of all-female populations include sex reversal, hermaphroditism (Hardy and Cole, 1981), and ecological factors that prevent the capture of males (Maslin, 1971). The first of these alternatives is refuted by the absence of males of any sizeclass, and the second is refuted by the absence of testicular material in females from these populations. The third possibility is considered to be unlikely, given the different techniques (e.g., diurnal vs. nocturnal collecting) and collectors that have contributed to the museum collections. There is cer-

TABLE 3. Specimens of $N$. arnouxii examined by cytology and electrophoresis and a summary of the results. $N=$ sample size, $2 n=$ diploid chromosome number; $F n=$ number of major chromosome arms (excluding the small arms of the acrocentric morph of pair 2).

\begin{tabular}{|c|c|c|c|c|c|}
\hline \multirow[b]{3}{*}{ Locality (map number) } & \multicolumn{3}{|c|}{ Cytogenetics } & \multicolumn{2}{|c|}{ Electrophoresis } \\
\hline & \multicolumn{2}{|c|}{ Karyotype } & \multirow[b]{2}{*}{$N$} & \multirow{2}{*}{$\begin{array}{l}\text { Heterozygosity } \\
\text { (direct count) }\end{array}$} & \multirow[b]{2}{*}{$N$} \\
\hline & $2 n$ & $\mathrm{~F} n$ & & & \\
\hline \multicolumn{6}{|l|}{ Bisexual populations: } \\
\hline Port Moresby, Papua New Guinea & $39 A$ & 40 & 3 & 0.03 & 3 \\
\hline Port Moresby, Papua New Guinea & $39 B$ & 40 & 1 & 0.07 & $1 *$ \\
\hline Cooktown, Australia (2) & 38 & 42 & 5 & 0.04 & 8 \\
\hline Mission Beach, Australia (3) & 38 & 42 & 3 & - & - \\
\hline Lizard Island, Australia (near 2) & 38 & 42 & 4 & - & - \\
\hline Efate, Vanuatu (25) & 28 & 42 & 15 & 0.01 & 3 \\
\hline \multicolumn{6}{|l|}{ Parthogenetic populations: } \\
\hline Viti Levu, Fiji (31) & 35 & 42 & 3 & 0.27 & 5 \\
\hline Niue, Cook Islands (35) & 35 & 42 & 1 & 0.27 & 1 \\
\hline New Caledonia (30) & 35 & 42 & 1 & - & - \\
\hline Tanna, Vanuatu (27) & 35 & 42 & 25 & - & - \\
\hline
\end{tabular}

\footnotetext{
* This specimen was examined at 29 loci (see Table 4).
} 
TABLE 4. Allele frequencies observed at 25 variable loci in $N$. arnouxii. At each locus, the alleles (= electromorphs) are designated by their electrophoretic mobility relative to the most common electromorph in the $2 n=$ 38 populations. Upper- and lowercase letters were defined as primitive and derived, respectively, relative to the $2 n=39$ Port Moresby samples for the phylogenetic analysis. Alleles without an accompanying letter were unique and had not reached fixation. These were ignored in this part of the analysis, as were the noninformative loci, $N d h$ and Pgm-2.

\begin{tabular}{|c|c|c|c|c|c|c|}
\hline \multirow[b]{3}{*}{ Locus } & \multirow[b]{3}{*}{ Alleles } & \multicolumn{5}{|c|}{ Frequency } \\
\hline & & \multicolumn{4}{|c|}{$\begin{array}{l}\text { Bisexual taxa } \\
\end{array}$} & \multirow{2}{*}{$\begin{array}{c}\text { Parthenogen } \\
2 n=35\end{array}$} \\
\hline & & $2 n=39 \mathrm{~A}$ & $2 n=39 \mathrm{~B}$ & $2 n=38$ & $2 n=28$ & \\
\hline Acon-1 & $\begin{array}{l}1.00 a \\
0.96 B\end{array}$ & $\begin{array}{r}0 \\
100\end{array}$ & $\begin{array}{r}0 \\
100\end{array}$ & $\begin{array}{r}100 \\
0\end{array}$ & $\begin{array}{r}100 \\
0\end{array}$ & $\begin{array}{r}100 \\
0\end{array}$ \\
\hline Acon-2 & $\begin{array}{l}1.00 \mathrm{a} \\
0.81 \mathrm{~B}\end{array}$ & $\begin{array}{r}0 \\
100\end{array}$ & - & $\begin{array}{r}100 \\
0\end{array}$ & $\begin{array}{r}100 \\
0\end{array}$ & $\begin{array}{r}100 \\
0\end{array}$ \\
\hline Sod & $\begin{array}{l}1.00 a \\
0.63 B \\
0.54 c \\
0.44 D\end{array}$ & $\begin{array}{r}0 \\
100 \\
0 \\
0\end{array}$ & $\begin{array}{r}0 \\
0 \\
0 \\
100\end{array}$ & $\begin{array}{r}100 \\
0 \\
0 \\
0\end{array}$ & $\begin{array}{r}0 \\
0 \\
100 \\
0\end{array}$ & $\begin{array}{r}0 \\
0 \\
100 \\
0\end{array}$ \\
\hline Fum & $\begin{array}{l}1.00 a \\
0.94 B\end{array}$ & $\begin{array}{r}0 \\
100\end{array}$ & $\begin{array}{r}0 \\
100\end{array}$ & $\begin{array}{r}0 \\
100\end{array}$ & $\begin{array}{r}100 \\
0\end{array}$ & $\begin{array}{r}100 \\
0\end{array}$ \\
\hline Got-1 & $\begin{array}{l}1.20 a \\
1.13 \\
1.05 C \\
1.00 b\end{array}$ & $\begin{array}{r}0 \\
0 \\
100 \\
0\end{array}$ & $\begin{array}{r}0 \\
0 \\
100 \\
0\end{array}$ & $\begin{array}{l}0.00 \\
0.06 \\
0.00 \\
0.94\end{array}$ & $\begin{array}{r}100 \\
0 \\
0 \\
0\end{array}$ & $\begin{array}{r}100 \\
0 \\
0 \\
0\end{array}$ \\
\hline Adh-1 & $\begin{array}{l}1.56 \mathrm{~A} \\
1.30 \mathrm{~b} \\
1.00 \mathrm{C}\end{array}$ & $\begin{array}{r}100 \\
0 \\
0\end{array}$ & $\begin{array}{l}- \\
-\end{array}$ & $\begin{array}{r}0 \\
0 \\
100\end{array}$ & $\begin{array}{r}0 \\
100 \\
0\end{array}$ & $\begin{array}{r}0 \\
100 \\
0\end{array}$ \\
\hline$A d h-2$ & $\begin{array}{l}1.63 \mathrm{a} \\
1.00 \mathrm{~B}\end{array}$ & $\begin{array}{r}0 \\
100\end{array}$ & - & $\begin{array}{r}0 \\
100\end{array}$ & $\begin{array}{r}100 \\
0\end{array}$ & $\begin{array}{r}0 \\
100\end{array}$ \\
\hline$I d h$ & $\begin{array}{l}1.00 a \\
0.90 B \\
0.81 c\end{array}$ & $\begin{array}{r}0 \\
100 \\
0\end{array}$ & $\begin{array}{r}0 \\
100 \\
0\end{array}$ & $\begin{array}{l}0.82 \\
0.18 \\
0.00\end{array}$ & $\begin{array}{r}0 \\
0 \\
100\end{array}$ & $\begin{array}{l}0.50 \\
0.00 \\
0.50\end{array}$ \\
\hline$L d h-A$ & $\begin{array}{l}1.00 \mathrm{~A} \\
0.90 \mathrm{~b}\end{array}$ & $\begin{array}{r}100 \\
0\end{array}$ & $\begin{array}{r}100 \\
0\end{array}$ & $\begin{array}{r}100 \\
0\end{array}$ & $\begin{array}{r}0 \\
100\end{array}$ & $\begin{array}{l}0.50 \\
0.50\end{array}$ \\
\hline$M p i$ & $\begin{array}{l}1.06 a \\
1.00 b \\
0.94 C\end{array}$ & $\begin{array}{r}0 \\
0 \\
100\end{array}$ & $\begin{array}{l}- \\
-\end{array}$ & $\begin{array}{r}0 \\
100 \\
0\end{array}$ & $\begin{array}{r}100 \\
0 \\
0\end{array}$ & $\begin{array}{l}0.50 \\
0.00 \\
0.50\end{array}$ \\
\hline$P e p-L P$ & $\begin{array}{l}1.24 a \\
1.16 \\
1.08 \\
1.00 B \\
0.95 \\
0.87\end{array}$ & $\begin{array}{l}0.00 \\
0.33 \\
0.00 \\
0.67 \\
0.00 \\
0.00\end{array}$ & $\begin{array}{l}- \\
- \\
- \\
-\end{array}$ & $\begin{array}{l}0.00 \\
0.00 \\
0.07 \\
0.56 \\
0.06 \\
0.31\end{array}$ & $\begin{array}{r}100 \\
0 \\
0 \\
0 \\
0 \\
0\end{array}$ & $\begin{array}{l}0.50 \\
0.00 \\
0.00 \\
0.50 \\
0.00 \\
0.00\end{array}$ \\
\hline Pep-LGG & $\begin{array}{l}1.38 \\
1.16 \mathrm{~A} \\
1.00 \\
0.96 b \\
0.88\end{array}$ & $\begin{array}{r}0 \\
100 \\
0 \\
0 \\
0\end{array}$ & $\begin{array}{l}0.50 \\
0.50 \\
0.00 \\
0.00 \\
0.00\end{array}$ & $\begin{array}{l}0.00 \\
0.12 \\
0.69 \\
0.00 \\
0.19\end{array}$ & $\begin{array}{r}0 \\
100 \\
0 \\
0 \\
0\end{array}$ & $\begin{array}{l}0.00 \\
0.50 \\
0.00 \\
0.50 \\
0.00\end{array}$ \\
\hline $6 P g d$ & $\begin{array}{l}1.11 \mathrm{a} \\
1.00 \mathrm{~B} \\
0.89 \mathrm{C}\end{array}$ & $\begin{array}{r}0 \\
100 \\
0\end{array}$ & $\begin{array}{r}0 \\
100 \\
0\end{array}$ & $\begin{array}{r}0 \\
100 \\
0\end{array}$ & $\begin{array}{r}0 \\
100 \\
0\end{array}$ & $\begin{array}{l}0.50 \\
0.00 \\
0.50\end{array}$ \\
\hline Sordh & $\begin{array}{l}1.20 \\
1.14 a \\
1.00 b \\
0.95 C \\
0.91\end{array}$ & $\begin{array}{l}0.00 \\
0.00 \\
0.00 \\
0.84 \\
0.16\end{array}$ & $\begin{array}{r}0 \\
0 \\
0 \\
100 \\
0\end{array}$ & $\begin{array}{r}0 \\
0 \\
100 \\
0 \\
0\end{array}$ & $\begin{array}{l}0.33 \\
0.67 \\
0.00 \\
0.00 \\
0.00\end{array}$ & $\begin{array}{l}0.00 \\
0.50 \\
0.50 \\
0.00 \\
0.00\end{array}$ \\
\hline Ald & $\begin{array}{l}1.16 \mathrm{a} \\
1.00 \mathrm{~B}\end{array}$ & $\begin{array}{r}0 \\
100\end{array}$ & $\begin{array}{r}0 \\
100\end{array}$ & $\begin{array}{r}0 \\
100\end{array}$ & $\begin{array}{r}100 \\
0\end{array}$ & $\begin{array}{r}100 \\
0\end{array}$ \\
\hline$G p-2$ & $\begin{array}{l}1.00 a \\
0.91 B\end{array}$ & $\begin{array}{r}0 \\
100\end{array}$ & $\begin{array}{r}0 \\
100\end{array}$ & $\begin{array}{r}100 \\
0\end{array}$ & $\begin{array}{r}100 \\
0\end{array}$ & $\begin{array}{r}100 \\
0\end{array}$ \\
\hline
\end{tabular}


TABle 4. Continued.

\begin{tabular}{|c|c|c|c|c|c|c|}
\hline \multirow[b]{3}{*}{ Locus } & \multirow[b]{3}{*}{ Alleles } & \multicolumn{5}{|c|}{ Frequency } \\
\hline & & \multicolumn{4}{|c|}{ Bisexual taxa } & \multirow{2}{*}{$\begin{array}{c}\text { Parthenogen } \\
2 n=35\end{array}$} \\
\hline & & $2 n=39 \mathrm{~A}$ & $2 n=39 \mathrm{~B}$ & $2 n=38$ & $2 n=28$ & \\
\hline$P k$ & $\begin{array}{l}1.00 a \\
0.90 B\end{array}$ & $\begin{array}{r}0 \\
100\end{array}$ & $\begin{array}{r}0 \\
100\end{array}$ & $\begin{array}{r}100 \\
0\end{array}$ & $\begin{array}{r}100 \\
0\end{array}$ & $\begin{array}{r}100 \\
0\end{array}$ \\
\hline$P g i$ & $\begin{array}{l}1.64 \\
1.00 \mathrm{~A} \\
0.72 \mathrm{~b}\end{array}$ & $\begin{array}{r}0 \\
100 \\
0\end{array}$ & $\begin{array}{r}0 \\
100 \\
0\end{array}$ & $\begin{array}{r}0 \\
100 \\
0\end{array}$ & $\begin{array}{l}0.17 \\
0.83 \\
0.00\end{array}$ & $\begin{array}{l}0.00 \\
0.50 \\
0.50\end{array}$ \\
\hline$T p i$ & $\begin{array}{l}1.00 a \\
0.92 B\end{array}$ & $\begin{array}{r}0 \\
100\end{array}$ & $\begin{array}{r}0 \\
100\end{array}$ & $\begin{array}{r}100 \\
0\end{array}$ & $\begin{array}{r}0 \\
100\end{array}$ & $\begin{array}{r}0 \\
100\end{array}$ \\
\hline$P g k$ & $\begin{array}{l}1.00 a \\
0.91 B \\
0.84 c\end{array}$ & $\begin{array}{r}0 \\
100 \\
0\end{array}$ & $\begin{array}{r}0 \\
100 \\
0\end{array}$ & $\begin{array}{r}100 \\
0 \\
0\end{array}$ & $\begin{array}{r}0 \\
0 \\
100\end{array}$ & $\begin{array}{r}0 \\
0 \\
100\end{array}$ \\
\hline$H k$ & $\begin{array}{l}1.08 a \\
1.00 b \\
0.91 C \\
0.86 d\end{array}$ & $\begin{array}{r}0 \\
0 \\
100 \\
0\end{array}$ & $\begin{array}{l}- \\
- \\
-\end{array}$ & $\begin{array}{r}0 \\
100 \\
0 \\
0\end{array}$ & $\begin{array}{r}100 \\
0 \\
0 \\
0\end{array}$ & $\begin{array}{l}0.00 \\
0.50 \\
0.00 \\
0.50\end{array}$ \\
\hline Ga3pd & $\begin{array}{l}1.00 a \\
0.93 B \\
0.88 \mathrm{C}\end{array}$ & $\begin{array}{r}0 \\
100 \\
0\end{array}$ & $\begin{array}{r}0 \\
100 \\
0\end{array}$ & $\begin{array}{r}100 \\
0 \\
0\end{array}$ & $\begin{array}{r}0 \\
0 \\
100\end{array}$ & $\begin{array}{r}0 \\
0 \\
100\end{array}$ \\
\hline$N d h$ & $\begin{array}{l}1.00 \\
0.95\end{array}$ & $\begin{array}{r}0 \\
100\end{array}$ & $\begin{array}{l}0.50 \\
0.50\end{array}$ & $\begin{array}{r}100 \\
0\end{array}$ & $\begin{array}{r}100 \\
0\end{array}$ & $\begin{array}{r}100 \\
0\end{array}$ \\
\hline Pgm-2 & $\begin{array}{l}1.29 \\
1.09 \\
1.00 \\
0.90 \\
0.62 \\
0.48 \\
0.39\end{array}$ & $\begin{array}{r}0 \\
0 \\
0 \\
100 \\
0 \\
0 \\
0\end{array}$ & $\begin{array}{r}0 \\
0 \\
0 \\
0 \\
100 \\
0 \\
0\end{array}$ & $\begin{array}{l}0.14 \\
0.06 \\
0.44 \\
0.06 \\
0.12 \\
0.12 \\
0.06\end{array}$ & $\begin{array}{r}0 \\
0 \\
0 \\
0 \\
100 \\
0 \\
0\end{array}$ & $\begin{array}{r}0 \\
0 \\
0 \\
0 \\
100 \\
0 \\
0\end{array}$ \\
\hline
\end{tabular}

tainly no difficulty in capturing large numbers of males from the western half of the range.

The genetic studies strongly implicate parthenogenetic reproduction in $N$. arnouxii. In the absence of recombination and mutation, parthenogenetic or gynogenetic organisms should maintain heterozygous combinations of genetic markers (Vrijenhoek, 1972; Uzzell and Darevsky, 1975; Parker and Selander, 1976; Cole, 1979; Turner et al., 1980; Echelle and Mosier, 1981; Dessauer and Cole, 1986) (but see Bogart and Licht [1986]). The absence of any segregation in the highly heterozygous karyotype ( $N=30$ individuals) and electrophoretic profile ( $N=6$ individuals) of the all-female $N$. arnouxii provides evidence for clonal inheritance due to parthenogenesis. While studies of the reproductive biology of the all-female lineage would be useful, the existing data provide a strong case for parthenogenetic reproduction in the eastern populations of this species.
All-female populations predominate in the eastern half of the range and, possibly, throughout Micronesia as well. The bisexual and parthenogenetic populations abut in Vanuatu, and both forms appear to coexist on Aneityum. However, it is not clear whether the female-biased populations from the Solomon islands (and some others to the northwest) represent a mixture of the two forms or are exclusively bisexual. An excess of females has been observed in some populations of bisexual geckos (e.g., Bustard, 1969) and may be a consequence of behavioral interactions (Bustard, 1970) or sampling artifacts (Maslin, 1971). The variation in the postmental scale that distinguishes the bisexual and parthenogenetic types within Vanuatu is of no use in the Solomon islands, since many males from this area also have the smaller scale. The possible presence of parthenogenetic females in the western half of the species range can only be evaluated by further genetic analysis. 
TABLE 5. Estimates of genetic divergence between the bisexual and parthenogenetic populations of $N$. arnouxii. Figures below the diagonal are genetic distances (Nei, 1978), and those above are corresponding proportions of loci with fixed allelic differences.

\begin{tabular}{|c|c|c|c|c|c|c|}
\hline \multirow[b]{2}{*}{ Karyotype (locality) } & \multirow{2}{*}{$\begin{array}{c}\text { Number } \\
\text { of loci }\end{array}$} & \multicolumn{5}{|c|}{ Samples } \\
\hline & & 1 & 2 & 3 & 4 & 5 \\
\hline $\begin{array}{c}\text { 1) } 2 n=39 \mathrm{~A} \text { (Port Moresby, } \\
\text { Papua New Guinea) } \\
\text { 2) } 2 n=39 \mathrm{~B} \text { (Port Moresby }\end{array}$ & 33 & - & 0.07 & 0.33 & 0.64 & 0.55 \\
\hline Papua New Guinea) & 29 & 0.10 & - & 0.29 & 0.48 & 0.48 \\
\hline 3) $2 n=38$ (Cape York, Australia) & 33 & 0.50 & 0.49 & - & 0.33 & 0.33 \\
\hline 4) $2 n=28$ (Efate, Vanuatu) & 33 & 1.00 & 0.75 & 0.73 & - & 0.09 \\
\hline 5) $2 n=35$ (Fiji and Niue) & 33 & 0.89 & 0.79 & 0.55 & 0.14 & - \\
\hline
\end{tabular}

The geographic distributions of parthenogenetic organisms and their bisexual relatives frequently differ, with the former being predominant at higher latitudes, on islands or in island-like habitats, and in more xeric or more disturbed habitats (Vandel, 1928; Suomalainen, 1950; Wright and Lowe, 1968; Glesener and Tilman, 1978; Cuellar, 1977; Bell, 1982). Although parthenogenesis is unusual among vertebrates, it is a common feature of the reptiles that have colonized the Pacific islands (Gibbons, 1985). The presence of so many parthenogens in the depauperate reptile faunas of the central and eastern Pacific islands has been attributed to their ability to found a population from a single female (Cuellar, 1977); this may also stem from the enhanced survival of low-density populations (Gerritson, 1980). The widespread occurrence of parthenogenetic $N$. arnouxii to the east of Vanuatu and, possibly, throughout Micronesia may simply reflect their superior colonizing ability.

The Origin of Parthenogenesis. -Unisexual species can arise through a spontaneous mutation within a bisexual population or by hybridization (Hubbs and Hubbs, 1932; reviewed by Suomalainen [1950], Schultz [1969], Cuellar [1974], Suomalainen et al. [1976], White [1978], and Lynch [1984]). The high karyotypic and electrophoretic heterozygosity of the parthenogenetic form of $N$. arnouxii suggest that they are of hybrid origin. The alternative hypothesis, the spontaneous evolution of parthenogenesis, would require that the high heterozygosity was achieved by the accumulation of mutations within the all-female lineage (see also Maslin [1971], Cuellar [1974], and Suo- malainen et al. [1976]). If this were the case, then there should also be very high clonal diversity. This prediction is not met by the available (but preliminary) data, which have revealed only a single genetic clone among unisexual $N$. arnouxii.

The genotypes of the parthenogens can be used to infer those of the bisexual taxa involved in their hybrid origin, if it is assumed that there has been negligible mutation and recombination within the unisexuals. The karyotype of the parthenogens has $2 n=35$ chromosomes and appears to be heterozygous for seven centric fusions and one pericentric rearrangement. These characteristics suggest that the two bisexual ancestors had $2 n=42$ and $2 n=28$ chromosomes, respectively. This interpretation differs slightly from an earlier analysis (based on fewer metaphases), which proposed that the parthenogen was a hybrid between bisexuals with $2 n=40$ and $2 n=30$ chromosomes (Moritz and King, 1985).

The predicted $2 n=28$ ancestor was identical in chromosome morphology and very similar in its allozyme mobilities to the extant population from northern Vanuatu. The ancestral karyotypic state for $N$. arnouxii is probably $2 n=42$ (all acrocentric chromosomes), with karyotypic change proceeding mainly by whole-arm translocation, as is the case in other polytypic gecko species (King, 1981; Moritz, 1986). Although this karyotype has not been observed as yet, it is the logical intermediate between the karyotypes of bisexual $N$. arnouxii. Given the assumption of a $2 n=42$ ancestor, each of the biarmed chromosomes shared by the $2 n=$ 28 sample from Vanuatu and a haploid genome from the parthenogens is a derived 


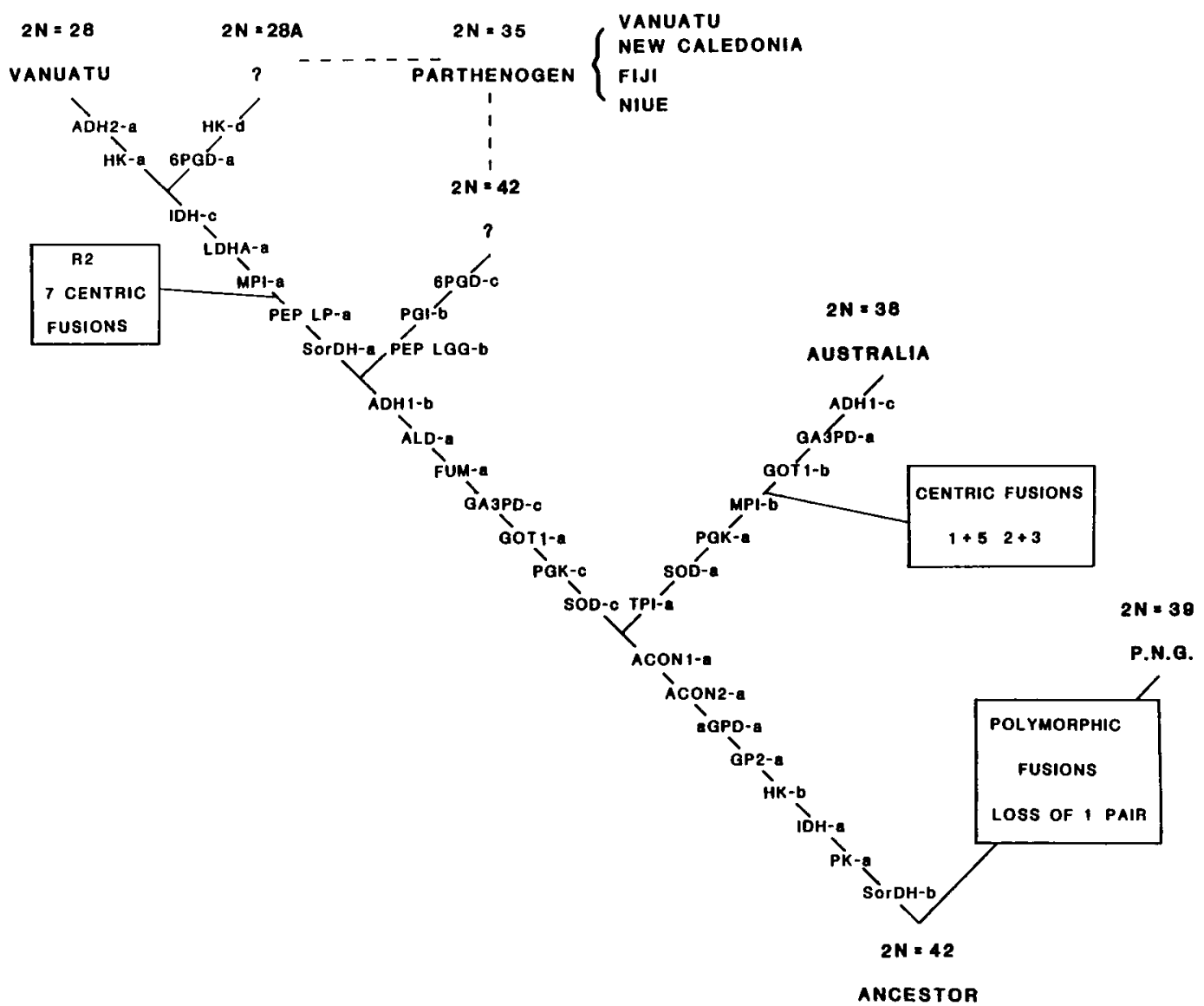

FIG. 7. Phylogenetic hypothesis for $N$. arnouxii based on chromosomal and electrophoretic data. Cytogenetic changes are indicated in the boxes, and biochemical steps are shown in alphabetical order. The $2 n=28 \mathrm{~A}$ and $2 n=42$ samples are hypothetical and were constructed from the characteristics of their presumed hybrid, the $2 n=35$ parthenogen (see text). Electrophoretic changes along each branch refer to the derived character-states in Table 4.

state and, thus, indicates close relationship. The close relationship between the predicted $2 n=28$ ancestor and the extant population from northern Vanuatu is corroborated by allozyme electrophoresis. The $2 n$ $=28$ sample and the parthenogens shared alleles at 30 of the 33 loci assayed.

The other predicted bisexual ancestor $(2 n=42)$ has not been observed among the bisexual populations surveyed. The predicted $2 n=42$ karyotype is identical to the presumed ancestral state and would differ from that of the polymorphic $2 n=40$ sample and the $2 n=38$ form by one and two whole-arm translocations, respectively. These high-chromosome-number bisexuals are also very distinct from the parthenogens at the loci assayed by allozyme electrophoresis.

The electrophoretic data can be used to derive explicit predictions of the genetic characteristics and phylogenetic affinities of the $2 n=42$ parent. Electromorphs of the putative $2 n=42$ bisexual were reconstructed from the profile of the parthenogen by removing the alleles attributable to the $2 n=$ 28 parent, i.e., those shared with the Vanuatu form. The data were coded by treating the locus as a character (see Buth, 1984) and ignoring unique polymorphic alleles. The chromosomally distinct Port Moresby population was selected as an outgroup to estimate the ancestral genotype for each locus. For this method of analysis, 23 of the 25 
variable loci were informative, and there were 34 shared and derived states (Table 4).

The phylogeny shown in Figure 7 requires the smallest possible number of steps (i.e., 34) to account for the electrophoretic data. According to this phylogeny, the $2 n=42$ parent was a member of the lineage leading to the extant $2 n=28$ population from northern Vanuatu. This in turn suggests that both of the predicted bisexual ancestors of the parthenogens were $N$. arnouxii (sensu latu). The conclusion accords with the lack of any obvious differences between parthenogenetic and bisexual $N$. arnouxii in their external morphology (T. Schwaner, pers. comm., C. Moritz, unpubl.). However, two congeners, $N$. vankampeni and $N$. galgajuga, are geographically close (although each has a restricted range) and morphologically similar to $N$. arnouxii and, thus, warrant further attention. The hybrid-origin hypothesis is being evaluated through further sampling of bisexual $N$. arnouxii from Melanesia.

The great majority of clonally reproducing vertebrates that have been carefully studied are interspecific hybrids (Schultz, 1969; White, 1978; Darevsky et al., 1985). However, there remain a few species of parthenogenetic lizards that do not appear to be hybrids between recognized bisexual species. In some cases (e.g., Hemidactylus vietnamensis [Darevsky et al., 1984] and Lepidodactylus lugubris [Cuellar and Kluge, 1972]), there is insufficient evidence on their bisexual relatives (reviewed by Moritz and King [1985]). Some other species, notably Lepidophyma flavimaculatum (Bezy, 1972) and Cnemidophorus lemniscatus (Vanzolini, 1970; Peccinini-Seale and Frota-Pessoa, 1974; Serena, 1984), include both bisexual and parthenogenetic populations, and it has been argued that these are not hybrids, since appropriate congeners are not present near their respective distributions. However, the evidence from $N$. arnouxii and another parthenogenetic gekko, Heteronotia binoei (Moritz, 1983, 1984), shows that parthenogenetic lineages can arise from hybridization between genetically distinct populations of the same nominal species. The patterns of chromosomal heterozygosity in parthenogenetic $C$. lemniscatus suggests that these may also be "intraspecific" hybrids
(Peccinini, 1971). In contrast, preliminary studies of allozyme variation in bisexual and parthenogenetic $L$. flavimaculatum revealed similar levels of heterozygosity (Bezy and Sites, 1987), so that it remains unlikely that these are hybrids between genetically distinct populations or species.

In both Heteronotia and Nactus, it is probable that the bisexual populations that hybridized in the past were, in fact, distinct biological species that have not diverged significantly in external morphology. Thus, the occurrence of "intraspecific" hybrid origins of parthenogenesis in Heteronotia and, probably, Nactus may simply reflect their morphological conservatism. It does not imply any fundamental differences between the hybrid-origin process in these lizards compared with other clonally reproducing vertebrates in which morphologically distinct (and thus taxonomically recognized) bisexual species are generally involved (reviewed by Schultz [1969], Cole [1975], White [1978], Darevsky et al. [1985]).

\section{ACKNOWLEDGMENTS}

I thank H. Cogger and T. Schwaner for their encouragement. H. Cogger, G. Mengden, D. Black, and A. Bauer provided live specimens. The staffs of the United States National Museum of Natural History, the Museum of Comparative Zoology (Harvard), the University of Michigan Museum of Zoology, the Bernice P. Bishop Museum, the Museum National d'Histoire Naturelle (Paris), the Naturhistorisches Museum (Basel), the American Museum of Natural History, the British Museum of Natural History, and the Australian Museum allowed access to preserved specimens. The cooperation of the fauna conservation authorities of Queensland (Australia), Papua New Guinea, Fiji, and Vanuatu is gratefully acknowledged. The manuscript received constructive criticism from $P$. Coleman, $T$. Dowling, A. Kluge, F. Kraus, R. Nussbaum, and W. H. Wagner, Jr. This study was supported by the Australian National University and NSF grants BSR 8517830 (to C. Moritz and W. M. Brown), BSR 8516645 (to W. M. Brown and W. R. Dawson) and BSR 8516627 (to J. Schall). 


\section{Literature Cited}

Avise, J. C., ANd C. F. Aquadro. 1982. A comparative summary of genetic distances in the vertebrates. Evol. Biol. 15:151-178.

BAKER, R. J., AND J. W. BICKHAM. 1986. Speciation by monobrachial centric fusions. Proc. Nat. Acad. Sci. USA 83:8245-8248.

BeLl, G. 1982. The Masterpiece of Nature. The Evolution and Genetics of Sexuality. Croom Helm, Canberra, Australia.

BezY, R. L. 1972. Karyotypic variation and the evolution of the lizards in the family Xantusiidae. Contrib. Sci. 227:1-29.

Bezy, R. L., AND J. W. Sites, JR. 1987. A preliminary study of allozyme variation in the lizard family Xantusiidae. Herpetologica. In press.

BogaRT, J. P., AND L. E. Licht. 1986. Reproduction and the origin of polyploids in hybrid salamanders of the genus Ambystoma.Can. J. Genet. Cytol. 28: 605-617.

BUSTARD, H. R. 1969. The population ecology of the gekkonid lizard Gehyra variegata in exploited forests in northern New South Wales. J. Anim. Ecol. 38:35-51.

- 1970. The role of behaviour in the natural regulation of numbers in the gekkonid lizard $\mathrm{Ge}$ hyra variegata. Ecology 51:724-728.

Buth, D. G. 1984. The application of electrophoretic data in systematic studies. Ann. Rev. Ecol. Syst. 15:501-522.

CAPANNA, E. 1982. Robertsonian numerical variation in animal speciation: Mus musculus, an emblematic model, pp. 155-177. In C. Barigozzi (ed.), Mechanisms of Speciation. Liss, N.Y.

CHRISTIDIS, L. 1984. Extensive chromosomal repatterning in two congeneric species: Pytilia melba L. and Pytilia phoenicoptera Swainson (Estrildidae: Aves). Cytogenet. Cell Genet. 36:641-648.

Cogger, H. C., and H. Heatwole. 1981. The Australian reptiles: Origins, biogeography, distribution patterns and island evolution, pp. 1331-1373. In A. Keast (ed.), Ecological Biogeography of Australia. Junk, The Hague, Neth.

COLE, C. J. 1975. Evolution of parthenogenetic species of reptiles, pp. 340-355. In R. Reinboth (ed.), Intersexuality in the Animal Kingdom. Springer-Verlag, Berlin, W. Ger.

- 1979. Chromosome inheritance in parthenogenetic lizards and evolution of allopolyploidy in reptiles. J. Hered. 70:95-102.

Cuellar, O. 1974. On the origin of parthenogenesis in vertebrates: The cytogenetic factors. Amer. Natur. 108:625-648.

. 1977. Animal parthenogenesis. Science 197: 837-843.

Cuellar, O., AND A. G. Kluge. 1972. Natural parthenogenesis in the gekkonid lizard Lepidodactylus lugubris. J. Genet. 61:14-26.

Darevsky, I. S., L. A. Kupriyanova, and V. V. RoshCHIN. 1984. A new all-female triploid species of gecko and karyological data on the bisexual Hemidactylus frenatus from Vietnam. J. Herpetol. 18:277-284.

DAREVSKY, I. S., L. A. KupRIYANOVA, AND T. UZZELl. 1985. Parthenogenesis in reptiles, pp. 413-526. In
C. Gans (ed.), Biology of the Reptilia, Vol. 15B. Wiley, N.Y.

DE Boer, P., P. van BuUl, R. VAN BeEk, R. ven DER Horven, and A. Natarajan. 1977. Chromosomal radiosensitivity and karyotype in mice using cultured peripheral blood and comparison with this system in man. Mut. Res. 42:379-394.

Dessauer, H. C., AND C. J. Cole. 1986. Clonal inheritance in parthenogenetic whiptail lizards: Biochemical evidence. J. Hered. 77:8-12.

Echelle, A. A., AND D. T. Mosier. 1981. All-female fish: A cryptic species of Menidia (Atherinidae). Science 212:1411-1413.

GerRITSON, J. 1980. Sex and parthenogenesis in sparse populations. Amer. Natur. 115:718-742.

Gibbons, J. 1985. The biogeography and evolution of Pacific island reptiles and amphibians, pp. 125142. In G. Grigg, R. Shine, and H. Ehrmann (eds.), Biology of Australasian Frogs and Reptiles. Roy. Zool. Soc. New South Wales, Sydney, Australia.

Glesener, R. R., AND D. Tilman. 1978. Sexuality and the components of environmental uncertainty: Clues from geographic parthenogenesis in terrestrial animals. Amer. Natur. 112:659-673.

Hardy, L. M., AND C. J. Cole. 1981. Parthenogenetic reproduction in lizards: Histological evidence. $\mathbf{J}$. Morphol. 170:215-237.

HubBs, C. L., AND L. C. HubBs. 1932. Apparent parthenogenesis in nature, in a form of fish of hybrid origin. Science 76:628-630.

Kezer, J., AND S. K. Sessions. 1979. Chromosome variation in the Plethodontid salamander Aneides ferreus. Chromosoma 71:65-80.

KING, M. 1981. Chromosome change and speciation in lizards, pp. 262-285. In W. R. Atchley and D. S. Woodruff(eds.), Evolution and Speciation. Cambridge Univ. Press, Cambridge, U.K.

KING, M., AND R. RoFE. 1976. Karyotypic variation in the Australian gekko Phyllodactylus marmoratus (Gray) (Gekkonidae: Reptilia). Chromosoma 54: 75-87.

KLUGE, A. G. 1983. Cladistic relationships among gekkonid lizards. Copeia 1983:465-475.

LYNCH, M. 1984. Destabilizing hybridization, general purpose genotypes and geographic parthenogenesis. Quart. Rev. Biol. 59:257-290.

Maslin, J. P. 1971. Parthenogenesis in reptiles. Amer. Zool. 14:361-380.

Moritz, C. 1983. Parthenogenesis in the endemic Australian lizard Heteronotia binoei. Science 220: 735-737.

- 1984. The origin and evolution of parthenogenesis in Heteronotia binoei (Gekkonidae). 1. Chromosome banding studies. Chromosoma 89 : 151-162.

1986. The population biology of Gehyra (Gekkonidae). 1. Chromosome change and speciation. Syst. Zool. 35:46-67.

Moritz, C., AND D. KING. 1985. Cytogenetic perspectives on parthenogenesis in the Gekkonidae, pp. 327-337. In G. Grigg, R. Shine, and H. Ehrmann (eds.), Biology of Australasian Frogs and Reptiles. Roy. Zool. Soc. New South Wales, Sydney, Australia.

NEI, M. 1978. Estimation of average heterozygosity 
and genetic distance from a small number of individuals. Genetics 89:583-590.

Parker, E. D., Jr., AND R. K. Selander. 1976. The organization of genetic diversity in the parthenogenetic lizard Cnemidophorus tesselatus. Genetics 84:791-805.

PeCCININI, D. 1971. Chromosome variation in populations of Cnemidophorus lemniscatus in the Amazonas Valley (Sauria, Teiidae). Cienc. Cult. 23: 133-136.

Peccinini-Seale, D., and D. Frota-Pessoa. 1974. Structural heterozygosity in parthenogenetic populations of Cnemidophorus lemniscatus (Sauria: Teiidae) from the Amazonas Valley. Chromosoma 47:439-451.

RichardSON, B. J., P. R. BAVERSTOCK, AND M. AdAMS. 1986. Allozyme Electrophoresis. Academic Press, Sydney, Australia.

Schultz, R. J. 1969. Hybridization, unisexuality, and polyploidy in the teleost Poeciliopsis (Poeciliidae) and other vertebrates. Amer. Natur. 103:605-619.

SCHWANER, T. D. 1980. Reproductive biology of lizards on the American Samoan Islands. Occas. Pap. Mus. Natur. Hist. Kans. 86:1-53.

Selander, R. K., M. H. Smith, S. Y. Yang, W. E. Johnson, AND J. B. Gentry. 1971. Biochemical polymorphism and systematics in the genus Peromyscus. 1. Variation in the old field mouse (Peromyscus polionotus). Stud. Genet. VI Univ. Texas Publ. 7103:49-90.

Serena, M. 1984. Distribution and habitats of parthenogenetic and sexual Cnemidophorus lemniscatus (Sauria: Teiidae) in Surinam. Copeia 1984: 713-719.

Suomalainen, E. 1950. Parthenogenesis in animals. Adv. Genet. 3:193-253.

Suomalainen, E., A. Saura, AND J. LoKkI. 1976.
Evolution of parthenogenetic insects. Evol. Biol. 9: 209-257.

Turner, B. J., B-L. H. Brett, E. M. RAsCh, AND J. S. BALSANO. 1980. Evolutionary genetics of a gynogenetic fish, Poecilia formosa, the amazon molly. Evolution 34:246-258.

UZZELL, T., AND I. S. DAREVSKY. 1975. Biochemical evidence for the hybrid origin of the parthenogenetic species of the Lacerta saxicola complex (Sauria: Lacertidae) with a discussion of some ecological and evolutionary implications. Copeia 1975:204222.

VANDEL, A. 1928. La parthénogénèse géographique: Contribution à l'étude biologique et cytologique de la parthénogénèse naturelle. Bull. Biol. France Belg. 62:164-281.

VAnzolini, P. E. 1970. Unisexual Cnemidophorus lemniscatus in the Amazonas Valley: A preliminary note (Sauria: Teiidae). Pap. Avul. Zool. 23:63-68.

VRIJENHOEK, R. C. 1972. Genetic relationships of unisexual-hybrid fishes to their progenitors using lactate dehydrogenase isozymes as gene markers (Poeciliopsis, Poeciliidae). Amer. Natur. 106:754766.

WALSH, J. B. 1982. Rate of accumulation of reproductive isolation by chromosome rearrangements. Amer. Natur. 120:510-532.

White, M. J. D. 1978. Modes of Speciation. Freeman, San Francisco, CA.

WRIGHT, J. W., AND C. H. Lowe. 1968. Weeds, polyploids, parthenogenesis, and the geographical and ecological distribution of all-female species of Cnemidophorus. Copeia 1968:128-138.

Corresponding Editors: T. J. Case R. C. Vrijenhoek 